\title{
The role of Staphylococcus species in the production of iru during the fermentation of African locust beans (Parkia biglobosa)
}

\author{
*Amao, J.A., Odunfa, S.A. and Mbom, C.N. \\ University of Ibadan, Faculty of Sciences, Department of Microbiology, Ibadan, Oyo State.
}

\begin{abstract}
Article history:
Received: 17 October 2017

Received in revised form: 20

November 2017

Accepted: 22 November 2017

Available Online: 1

December 2017
\end{abstract}

Keywords:

Staphylococcus spp.,

Bacillus spp.,

African locust bean,

Iru,

Fermentation

DOI:

https://doi.org/10.26656/fr.2017.2(2).014

\begin{abstract}
Staphylococcus spp. are regularly isolated from iru, but the role(s) they play in the fermentation process has not yet been determined; this work thus seeks to determine if Staphylococcus spp. isolated from iru play any role in the fermentation of African locust bean. Bacillus spp. and Staphylococcus spp. isolated from spontaneously fermented African locust bean (iru) were used to ferment African locust beans. The temperature, $\mathrm{pH}$ and moisture content were determined as fermentation progress while the total soluble sugar and total free amino acid were determined after fermentation. The microbial load for the three iru products increased gradually until the end of fermentation. The total free amino acids increased in all three iru $\left(1.10,1.51\right.$ and $2.35 \mathrm{mg}$ leucine $\mathrm{ml}^{-1}$ for Staphylococcus spp. iru, Bacillus spp. iru and iru produced with combination of the two species of bacteria) when compared with that of the unfermented bean, while the total soluble sugars reduced after fermentation with Staphylococcus spp. iru having 3.84, Bacillus spp. iru has 3.60, and the unfermented bean has $5.30 \mathrm{mg}$ glucose $\mathrm{ml}^{-1}$ total soluble sugar. The increased free amino acids in the iru fermented with Staphylococcus spp. and the ability of the Staphylococcus spp. to produce lipase showed that Staphylococcus spp. isolated from iru has the ability to ferment African locust bean and carry out the lipolytic activity during the fermentation.
\end{abstract}

\section{Introduction}

Iru-a condiment produced from the fermentation of the dried, dehulled boiled seeds of African locust beans tree- Parkia biglobosa, which is a perennial leguminous tree of the sub-family Mimosoideae family Leguminosae. Local production of iru involves the boiling of the dried seeds on fire for about $24 \mathrm{~h}$ to soften the testa and cotyledons, the boiled, soft seeds are pressed in the mortar with feet to remove the softened testa; after which the seeds are washed to remove the testa from the cotyledon and then boiled for another 1-2 hours then fermented (Odunfa and Oyewole, 1986).

The popularity and acceptance of Locust bean dawadawa were not in doubt as it is used in soups by communities in several parts of Nigeria (Kolapo et al., 2007). Apart from the improvement of sensory properties, condiments add nutritional values to foods, providing dietary fiber, energy, minerals, and vitamins (Kolapo et al., 2007). Iru is an important source of riboflavin and it contains the highest riboflavin content when compared to some other common plant foods (Pelig-Ba, 2009).

It is clear that the fermentation of vegetable proteins into condiments is usually initially mediated by diverse microbial flora, which at the long-run eventually becomes gram positive flora (Achi, 2005); though the contributions of this microbial flora to the properties of the products are not totally understood (Iwuoha and Eke, 1996).

The co-dominance of Staphylococcus and Bacillus species was the typical microflora of the fermenting beans (Achi, 1992), but the contribution of the accompanying flora of the fermenting substrate is determined by the composition of the substrate and the hygiene or hygienic measures put in place during production (Achi, 2005).

Bacillus species were reported to be most responsible for alkaline fermentation of vegetable condiments, but several works also have identified some other microorganisms in iru production to include Micrococcus, Leuconostoc, and Enterobacteriaceae, (Omafuvbe et al., 2002; Ogunshe et al., 2008) with Bacillus spp. and Staphylococcus spp. being the major microflora (Odunfa, 1991).

Lues et al. (2011), reported the presence of Staphylococcus in a commercially produced traditional 
beer like circa, which had $10^{4} \mathrm{CFU} / \mathrm{ml}$ and scomfana which had $10^{5} \mathrm{CFU} / \mathrm{ml}$; he discovered that the Staphylococcus spp. include $S$. aureus, S. epidermidis, $S$. xylosus, S. hominis, S. capitis and S. saprophyticus. Omafuvbe et al. (2000) found out that Staphylococcus was only present at the early stage of soybean fermentation to produce soy-iru. Ogunshe et al. (2007) isolated non-sporing Staphylococcus spp. and some Bacillus spp. from the fermenting Prosopis Africana cotyledons during the controlled fermentation of afiyo and he concluded that Staphylococcus did not appear to play a major role in the production of the condiment. Bacillus spp., Staphylococcus aureus and $S$. saprophyticus were the characterized bacterial species during the microbial studies on aisa- a fermented food condiment from Albizia saman; fermented in the laboratory (Ogunshe et al., 2006). Cultures of B. subtilis, $B$. licheniformis, and S. xylosus had been isolated and identified as predominant micro-organisms associated with spontaneous fermentation of Lanhouin condiment (Anihouvi et al., 2007).

A gradual increase of $S$. xylosus was noted during the first $60 \mathrm{~h}$ of fermentation, followed by a slight decrease in the final microbial load (Anihouvi et al., 2012). S. xylosus had an important proteolytic activity, leading to the increase of $\mathrm{pH}$ during the spontaneous fermentation of fish (Anihouvi et al., 2007). The microbial flora isolated from laboratory prepared anyifermented Samanea saman; include different species of Bacillus and a few Staphylococci to include $S$. saprophyticus, which did not appear to play any major role in fermentation (Okonko, 2008).

The total sugar decreased significantly in soydaddawa fermentation while reducing sugar increased in the first 12 hours and then decreased, which was suggested to be as a result of utilization of soluble sugars by the increasing population of the microorganism, but the addition of $1 \%$ salt to the substrate resulted in the increase of free amino acids and the proteolytic activities which are thought to enhance flavor (Omafuvbe, 2006).

Ogunshe et al. (2007), reported an increase in the total sugars during the first $24 \mathrm{~h}$ of fermentation, followed by a subsequent decrease on the second day of fermentation; and the peak came on the 3rd and 6th days of fermentation, but the total amino acids level was found to increase throughout the fermentation period. Uaboi-Egbenni et al. (2009) reported that the highest mean value obtained for reducing sugar was $1.25 \mathrm{mg}$ at the fourth day of fermentation,

Ogunjobi et al. (2005) reported a slight increase in the moisture contents of brined samples of Irish potatoes, Pelig-Ba (2009) reported an increase in moisture during the fermentation of African locust beans.
The objective of this work is to determine what possible role(s) Staphylococcus spp. play in the fermentation of African locust beans to produce iru; since Staphylococcus spp. are regularly isolated from iru.

\section{Materials and methods}

\subsection{African locust bean seeds}

Dried of African locust bean seeds (Parkia biglobossa) were purchased at Bodija market in Ibadan.

\subsection{Fermentation of iru in the laboratory}

Seeds were cooked in a pressure pot for about $2 \mathrm{~h}$, the swollen seeds were rubbed in between palms to remove the testa, the hard seeds were removed during washing. The cotyledons were then boiled for another 30 minutes and drained in a sieve. Fifty (50 g) grams of boiled, dehulled seeds were weighed into small DANA plastics with airtight cover and sterilized at $121^{\circ} \mathrm{C}$ for 15 minutes, this was then allowed to cool down. $0.5 \mathrm{ml}$ of inoculums was used to inoculate the cooked beans. The inoculated beans were wrapped in towels and incubated for $48 \mathrm{~h}$.

\subsection{Determination of inoculums size}

The representative of each bacteria group was grown on agar at $37^{\circ} \mathrm{C}$ for $18 \mathrm{~h}$; each of the cultures was suspended in $10 \mathrm{ml}$ sterile $1 \% \mathrm{NaCl}$ solution (the three species of each bacteria is mixed together and well mixed before dilution), diluted to give an absorbance of 0.03 at $540 \mathrm{~nm}$ in a spectrophotometer, $0.5 \mathrm{ml}$ of this dilution was used to inoculate the cooked beans (Omafuvbe et al., 2002; Omafuvbe, 2006) aseptically (this gives about $10^{4}$ cells $\mathrm{g}^{-1}$ wet wt.); the suspension was mixed equally for two bacteria membered mixed culture. Three Staphylococcus spp. (S. saprophyticus, S. xylosus and $S$. epidermidis) and three Bacillus spp. (B. subtilis, B. pumilus and B. licheniformis) previously isolated from iru (gotten from the food microbiology laboratory of Microbiology department of University of Ibadan) were used.

\subsection{Microbiological analysis}

The microbial load was determined, by aseptically collecting samples at 24-hour interval $(0,24$, and 48 hours) during fermentation, $1 \mathrm{~g}$ of the samples (each) was transferred to sterile distilled water and well shaken. Ten-fold serial dilutions in the same diluents were prepared and used. Aerobic mesophilic counts were done after incubation at $37^{\circ} \mathrm{C}$ on plate count agar (PCA), using $1 \mathrm{ml}$ of different dilutions for the pour plate method; analyses were carried out in triplicates at specified times.

\section{$2.5 \mathrm{pH}$ and temperature measurement}

The temperature and $\mathrm{pH}$ changes during 
fermentation were measured at 0,24 and $48 \mathrm{~h}$. The $\mathrm{pH}$ was determined by mixing $1 \mathrm{~g}$ of the fermenting mash with $10 \mathrm{ml}$ of distilled water and the suspension was used for the $\mathrm{pH}$ determination using a $\mathrm{pH}$ meter (using EXTECH pH100).

\subsection{Moisture content}

The moisture contents were determined for the products as fermentation progresses at 0,24 and $48 \mathrm{~h}$ by weighing $1 \mathrm{~g}$ of each fermenting mashes on petri dish and put in the oven at $80^{\circ} \mathrm{C}$, the weight was checked and recorded at intervals till a constant weight was obtained, the final weight is then subtracted from the initial weight and the answer was divided by the initial weight and multiplied by 100 to get the percentage moisture content.

\subsection{Preparation of extracts}

For the analysis of total free amino acids and total soluble sugar, approximately $5 \mathrm{~g}$ of the samples after drying at $80^{\circ} \mathrm{C}$ in the oven for $24 \mathrm{~h}$ was mixed with $70 \%$ ethanol and ground in a mortar; the suspension was then washed with $5 \mathrm{ml} \mathrm{n}$-hexane to extract the oil, this was then filtered, using Whatman filter paper number 1 and the filtrate was used for analysis.

\subsection{Determination of total free amino acids}

The total free amino acids of the African locust bean before and after fermentation were determined by the ninhydrin colorimetric method of Rosen (1957) using leucine as the standard. To $1 \mathrm{ml}$ of the extract was added $0.5 \mathrm{ml}$ of cyanide-acetate buffer and $0.5 \mathrm{ml}$ of $3 \%$ ninhydrin in Methyl Cellosolve (2-Methoxyl Ethanol); the mixture was heated for 15 minutes in $100^{\circ} \mathrm{C}$ boiling water, $5 \mathrm{ml}$ of $\mathrm{n}$-Propanol water mixture was added and shaken vigorously. The color was read in a spectrophotometer at $570 \mathrm{~nm}$ after cooling and the concentration of amino acids was calculated from a standard curve based on the known concentration of leucine.

\subsection{Determination of total soluble sugar}

The total soluble sugar of the African locust bean before and after fermentation was determined by anthrone reaction method, with glucose as the standard (Omafuvbe et al., 2004). The extract was suitably diluted and to $1 \mathrm{ml}$ of this was added $4 \mathrm{ml}$ of freshly prepared anthrone reagent and the mixture heated for $10 \mathrm{~min}$ and cool rapidly. The color change was read at $630 \mathrm{~nm}$ in a spectrophotometer and the concentration of the total soluble sugar was calculated from the standard curve based on the concentration of glucose.

\subsection{Enzyme assay}

Staphylococcus spp. isolated from iru were cultivated in $20 \mathrm{ml}$ each separately and together nutrient broth and incubated at $37^{\circ} \mathrm{C}$ in a shaking incubator (150 $\mathrm{rpm})$ for 72 hours. Enzyme production and growth of culture were determined at the end of each cultivation period, the broth was centrifuged at $10,000 \mathrm{rpm}$ at $4^{\circ} \mathrm{C}$. The clear supernatant was collected as a source of enzymes. Proteinase (using the modified casein digestion method of Kunitz (1974)), amylase (assayed by the method of Bernfield (1955)) and lipase production (assayed by modifying the method of Yong and Wood (1977)) over the 72-hour cultivation period was determined through assay of enzymes activity.

\subsection{Statistical analysis}

The data obtained were subjected to analysis of variance (ANOVA) and, Duncan's multiple range tests were used to significantly differentiate the means of the sample treatments $(\mathrm{P} \leq 0.05)$.

\section{Results and Discussion}

\subsection{Change in microbial count}

Table 1 shows the growth pattern of the inocula, change in temperature and $\mathrm{pH}$ of the fermenting mash as fermentation progresses. There was an appreciable increase in the microbial count of all the fermenting mash, with that of Staphylococcus spp. fermented iru rose from an initial of $4.17(\log \mathrm{CFU} / \mathrm{ml})$ to 7.38 after 24 hours of fermentation and 10.38 after 48 h, Bacillus spp. iru had an initial of $4.2(\log \mathrm{CFU} / \mathrm{ml})$ that increased to 7.45 and 10.59 at 24 and $48 \mathrm{~h}$ of fermentation respectively; the microbial count for the iru produced with the two bacteria was $4.25(\log \mathrm{CFU} / \mathrm{ml})$ at the start of fermentation, this increased to 7.50 and 10.74 at $24 \mathrm{~h}$ and $48 \mathrm{~h}$ respectively.

The increased microbial count is in agreement with the result of Odunfa and Komolafe (1989), but the increase in the number of Staphylococcus spp. till the end of the fermentation disagrees with that of Ogbadu and Okagbue (1988) who reported the absence of Staphylococcus in the $48 \mathrm{~h}$ fermentation of dawadawa, and that of Omafuvbe et al. (2000) who found out that Staphylococcus was only present at the early stage of fermentation, this may be because Staphylococcus spp. has the ability to utilize the nutrients found in African locust bean.

\subsection{Change in temperature}

There was an increase in the temperature of all the fermenting mashes from a start of around $23.6^{\circ} \mathrm{C}$ to a final temperature of $28.9^{\circ} \mathrm{C}$ for Bacillus spp. fermented beans and $29.3^{\circ} \mathrm{C}$ for the Staphylococcus spp. fermented locust beans while the one fermented with the two species of bacteria has a final temperature of $29.5^{\circ} \mathrm{C}$ (Table 1); this is in agreement with the report of Jonathan et al. (2011). 
Table 1. Changes in the microbial load, temperature and $\mathrm{pH}$ during the production of iru with two different bacteria at different sampling hour

\begin{tabular}{|c|c|c|c|}
\hline & $\begin{array}{l}\text { Microbial Load } \\
(\log \text { CFU/ml) }\end{array}$ & Temperature $\left({ }^{\circ} \mathrm{C}\right)$ & $\mathrm{pH}$ \\
\hline \multicolumn{4}{|l|}{ Control } \\
\hline $0 \mathrm{~h}$ & NG & - & - \\
\hline $24 \mathrm{~h}$ & NG & - & - \\
\hline $48 \mathrm{~h}$ & NG & - & - \\
\hline \multicolumn{4}{|l|}{ Staphylococcal Iru } \\
\hline $0 \mathrm{~h}$ & $4.17 \pm 0.01^{\mathrm{a}}$ & $23.6 \pm 0.43^{\mathrm{a}}$ & $6.46 \pm 0.03^{\mathrm{a}}$ \\
\hline $24 \mathrm{~h}$ & $7.38 \pm 0.02^{\mathrm{b}}$ & $26.8 \pm 0.36^{b}$ & $7.59 \pm 0.01^{\mathrm{b}}$ \\
\hline $48 \mathrm{~h}$ & $10.38 \pm 0.05^{\mathrm{c}}$ & $29.3 \pm 0.98^{c}$ & $7.70 \pm 0.04^{\mathrm{c}}$ \\
\hline \multicolumn{4}{|l|}{ Bacillus Iru } \\
\hline $0 \mathrm{~h}$ & $4.20 \pm 0.01^{\mathrm{a}}$ & $23.7 \pm 0.43^{\mathrm{a}}$ & $6.45 \pm 0.03^{\mathrm{a}}$ \\
\hline $24 \mathrm{~h}$ & $7.45 \pm 0.02^{\mathrm{b}}$ & $26.8 \pm 0.36^{\mathrm{b}}$ & $7.56 \pm 0.01^{\mathrm{b}}$ \\
\hline $48 \mathrm{~h}$ & $10.59 \pm 0.05^{\mathrm{c}}$ & $28.9 \pm 0.98^{c}$ & $7.65 \pm 0.04^{\mathrm{c}}$ \\
\hline \multicolumn{4}{|c|}{ Bacillus + Staphylococcal Iru } \\
\hline $0 \mathrm{~h}$ & $4.25 \pm 0.01^{\mathrm{a}}$ & $23.5 \pm 0.43^{\mathrm{a}}$ & $6.46 \pm 0.03^{\mathrm{a}}$ \\
\hline $24 \mathrm{~h}$ & $7.50 \pm 0.02^{\mathrm{b}}$ & $26.6 \pm 0.36^{\mathrm{b}}$ & $7.55 \pm 0.01^{\mathrm{b}}$ \\
\hline $48 \mathrm{~h}$ & $10.74 \pm 0.05^{\mathrm{c}}$ & $29.5 \pm 0.98^{c}$ & $7.84 \pm 0.04^{\mathrm{c}}$ \\
\hline
\end{tabular}

$\mathrm{NG}=$ No Growth

Mean values followed by the same letter in the column are not significantly different by Duncan's Multiple Range test (P $\leq 0.05$ )

\subsection{Change in $\mathrm{pH}$}

The $\mathrm{pH}$ of the Staphylococcus spp. fermented locust beans increased from 6.46 at $0 \mathrm{~h}$ to 7.59 at $12 \mathrm{~h}$ and $24 \mathrm{~h}$, then declined to 7.55 at $36 \mathrm{~h}$, after which it rose again to 7.70 at $48 \mathrm{~h}$ of fermentation. The $\mathrm{pH}$ of the Bacillus spp. fermented beans increased from 6.45 at $0 \mathrm{~h}$ and 7.61 at $12 \mathrm{~h}$ of fermentation then declined to 7.56 and 7.55 at 24 and $36 \mathrm{~h}$ of fermentation respectively then increased to 7.65 after $48 \mathrm{~h}$ of fermentation. The $\mathrm{pH}$ of the locust beans fermented with the combination of the two species of organisms rose from 6.46 at $0 \mathrm{~h}$ to 7.62 at $24 \mathrm{~h}$, then declined to 7.55 at $24 \mathrm{~h}$, then rose to 7.57 and 7.84 at 36 $\mathrm{h}$ and $48 \mathrm{~h}$ of fermentation respectively (Table 1); this agrees with the results of Omafuvbe et al. (2002); the increase in $\mathrm{pH}$ may be due to the ability of the bacteria to carry out proteolysis, producing ammonia, which increases the $\mathrm{pH}$.

\subsection{Free amino acids}

Table 2 shows the changes in the free amino acids and total soluble sugars in the fermented mash. The free amino acids of the unfermented mash increased from 0.74 to 1.10 in the Staphylococcus spp. fermented iru, 1.51 in the Bacillus spp. fermented iru and 2.35 in the iru fermented with the two bacterial species after fermentation. There is a significant difference between the free amino acids of the iru fermented with both species of bacteria and the one fermented with Staphylococcus spp. but not between Staphylococcus spp. fermented iru and the one fermented with Bacillus spp. There was no significant difference between the free amino acids of the Bacillus spp. fermented iru and the one fermented with the two species of bacteria.

Table 2. Change in free amino acids and total soluble sugars of iru produced with two different bacteria

\begin{tabular}{|c|c|c|}
\hline Organism & $\begin{array}{c}\text { Free Amino } \\
\text { Acids }\left(\mathrm{mg}^{-1}\right) \\
\left.\text { leucine } \mathrm{ml}^{-1}\right)\end{array}$ & $\begin{array}{l}\text { Total Soluble } \\
\text { Sugars }(\mathrm{mg} \\
\left.\text { glucose } \mathrm{ml}^{-1}\right)\end{array}$ \\
\hline Staphylococcal iru & $1.10 \pm 0.26^{\mathrm{a}}$ & $3.84 \pm 0.46^{\mathrm{ab}}$ \\
\hline Bacillus iru & $1.51 \pm 0.26^{\mathrm{ab}}$ & $3.60 \pm 0.46^{\mathrm{ab}}$ \\
\hline $\begin{array}{l}\text { Bacillus }+ \text { Staphylococcal } \\
\text { iru }\end{array}$ & $2.35 \pm 0.26^{\mathrm{b}}$ & $2.83 \pm 0.46^{\mathrm{a}}$ \\
\hline Unfermented Bean & $0.74 \pm 0.26^{\mathrm{a}}$ & $5.30 \pm 0.46^{\mathrm{b}}$ \\
\hline
\end{tabular}

Values are Means Scores \pm Standard Error. Mean values followed by the same superscript in the column are not significantly different by Duncan's Multiple Range test $(\mathrm{P} \leq 0.05)$

The increase in free amino acids in the Staphylococcus spp. fermented iru, Bacillus spp. fermented iru and the iru fermented with both species is in agreement with that of Odunfa and Adewuyi (1985b) who reported the highest value of $1.6 \mathrm{mg} / \mathrm{ml}$ of extract in amino acid content at the $36 \mathrm{~h}$ of fermentation; Odunfa and Adewuyi (1985a) who reported an efficient hydrolysis of locust bean protein to amino acids between 1.98 to $2.6 \mathrm{mg} / \mathrm{ml}$ and that of Omafuvbe et al. (2002), who reported a continuous increase in the free amino acids contents; it also agrees with what Anihouvi et al. (2012), reported in the controlled Lanhouin. 
The relationship shown between the free amino acids of the Staphylococcal iru and Bacillus iru may be due to the ability of both bacterial species to hydrolyse the African locust bean protein to produce amino acids, but the significant differences shown by the iru produced by the two bacterial species shows that the two bacterial species in combination have the ability to improve the number of free amino acids produced during the production of iru.

\subsection{Total soluble sugars}

The total soluble sugars of the unfermented beans of 5.30 decreased to 3.84 when fermented with Staphylococcus spp. and 3.60 when fermented with Bacillus spp. but it was 2.83 when fermented with the two species of bacteria (Table 2). There was no significant difference between the total soluble sugar of the iru fermented with Bacillus spp., Staphylococcus spp. and the unfermented beans; but there was a significant difference between the iru fermented with both species of bacteria and the unfermented beans. There was no significant difference between the total soluble sugar of the iru fermented with Bacillus spp., Staphylococcus spp. and the iru fermented with the two species of bacteria. This result agrees with that of Omafuvbe et al. (2004), who reported a substantial decrease in the total soluble sugar during the fermentation of melon, also with that of Omafuvbe (2006). The decrease in total soluble sugars may be due to the utilization of the sugars by the bacteria for their growth.

\subsection{Moisture content}

The moisture content of the products at different hours of fermentation is shown in Table 3 , no significant difference was observed in the percentage moisture content of the iru fermented with Bacillus spp., Staphylococcus spp. and the iru fermented with both Staphylococcus spp. and Bacillus spp. in combination; but there was a significant difference in their percentage moisture content of iru for each different product at different hours of fermentation as the moisture content of the iru fermented with both Staphylococcus spp. increased from an initial of 64.73 to 65.38 at $24 \mathrm{~h}$ and 67.43 at $48 \mathrm{~h}$ of fermentation, while the moisture content of the iru fermented with Bacillus spp. increased from 64.71 at $0 \mathrm{~h}$ to 65.76 at $24 \mathrm{~h}$ and 67.75 at $48 \mathrm{~h}$. The moisture content of the iru fermented with both Staphylococcus spp. and Bacillus spp. in combination rose from an initial of 64.71 to 65.86 and 67.98 at $24 \mathrm{~h}$ and $48 \mathrm{~h}$ of fermentation respectively.

The increase observed in the moisture content of African locust beans during fermentation is in line with the report of Ogunjobi et al. (2005) and Jonathan et al. (2011), who reported an increase in the moisture content of substrates fermentation.
The ability of the Staphylococcus spp. isolated from iru to carry out amylolytic, lipolytic and proteolytic activities (Figure 1) was in agreements with the report of Mossel (1982), that Staphylococcus spp. isolated from foods produced extracellular enzymes of which lipase is a major; this is however in contrast with the report of Aderibigbe and Odunfa (1990), who reported that no extracellular lipolytic activity was detected for some Bacillus spp. isolated from iru, when grown in nutrient broth. Staphylococcus epidermidis and the mixed culture of the three Staphylococcus spp. showed high lipolytic and proteolytic activities, this is in agreement with the work of Anihouvi et al. (2012), who reported that $S$. xylosus could play a significant role in aroma development by the production of ammonia.

Table 3. Change in the moisture content of iru produced by different inocula as fermentation progresses

\begin{tabular}{lcc}
\hline \multicolumn{1}{c}{ Product } & $\begin{array}{c}\text { Hour of } \\
\text { fermentation }\end{array}$ & $\begin{array}{c}\text { Moisture } \\
\text { Content (\%) }\end{array}$ \\
\hline \multirow{3}{*}{ Staphylococcus Iru } & $0 \mathrm{~h}$ & $64.73^{\mathrm{a}}$ \\
& $24 \mathrm{~h}$ & $65.38^{\mathrm{b}}$ \\
& $48 \mathrm{~h}$ & $67.43^{\mathrm{c}}$ \\
\hline \multirow{3}{*}{ Bacillus Iru } & $0 \mathrm{~h}$ & $64.71^{\mathrm{a}}$ \\
& $24 \mathrm{~h}$ & $65.76^{\mathrm{b}}$ \\
& $48 \mathrm{~h}$ & $67.75^{\mathrm{c}}$ \\
\hline \multirow{2}{*}{ Bacillus +} & $0 \mathrm{~h}$ & $64.71^{\mathrm{a}}$ \\
Staphylococcus Iru & $24 \mathrm{~h}$ & $65.86^{\mathrm{b}}$ \\
\hline
\end{tabular}

Mean values followed by the same superscript are not significantly different by Duncan's Multiple Range test $(\mathrm{P} \leq 0.05)$

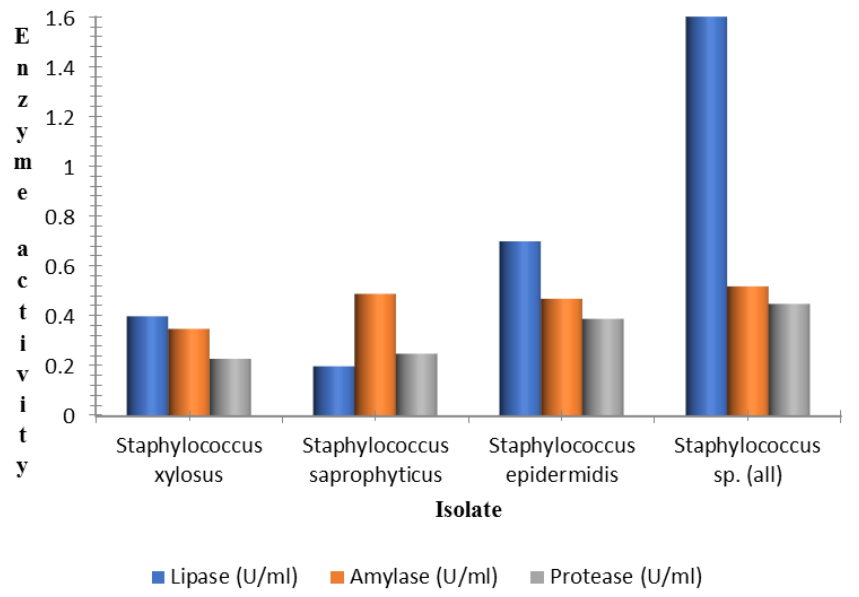

Figure 1. Enzyme assay for three Staphylococcus spp. Isolated from iru.

\section{Conclusion}

The increase in $\mathrm{pH}$ during the fermentation of iru produced with Staphylococcus spp. and the increase in free amino acids proved that Staphylococcus spp. isolated from iru has the ability to ferment African locust 
bean, and thus play a role in the breaking down of proteins in African locust bean to amino acids; but the significant differences in the free amino acids and total soluble sugars observed in the iru produced with single bacterial species compared with that of the iru produced with the two bacterial species shows that they do better together than in singleton. Howbeit, the ability of the three Staphylococcus spp. isolated from iru to produce extracellular enzymes (Lipase, Protease, and Amylase) in a relatively high quantity provides a reason for the better products when Staphylococcus spp. are involved in the fermentation than when only Bacillus spp. is used.

\section{Acknowledgment}

The authors wish to acknowledge the effort of Dr. O. S. Bello of the Department of Pure and Applied Chemistry, LAUTECH, Ogbomoso; for his help and encouragement on this work.

\section{References}

Achi, O.K. (1992). Microorganisms associated with natural fermentation of Prosopis Africana seeds for the production of Okpiye. Plant Foods for Human Nutrition, 42(4), 297-304. https://doi.org/10.1007/ BF02194090

Achi, O.K. (2005). The potential for upgrading traditional fermented foods through biotechnology. African Journal of Biotechnology, 4(5), 375-380.

Aderibigbe, E.Y. and Odunfa S.A. (1990). Growth and extracellular enzyme production by strains of Bacillus species isolated from fermenting African locust bean, iru. Journal of Applied Bacteriology, 69 (5), 662-671. https://doi.org/10.1111/j.13652672.1990.tb01560.x

Anihouvi, V.B, Sakyi-Dawson, E., Ayernor, G.S. and Hounhouigan, J.D. (2007). Microbiological Changes in naturally fermented cassava fish (Pseudotolithus spp.) for Lanhouin production. International Journal of Food Microbiology, 116(2), 287-291. https:// doi.org/10.1016/j.ijfoodmicro.2006.12.009

Anihouvi, V.B., Kpoclou, E.Y. and Hounhouigan, J.D. (2012). Use of starter cultures of Bacillus and Staphylococcus in the controlled fermentation of Lanhouin, a traditional fish-based condiment from West Africa. African Journal of Microbiology Research, 6, 4767-4774

Iwuoha, C.I. and Eke, O.S. (1996). Nigeria indigenous fermented foods: their traditional process operations, inherent problems, improvements and current status. Food Research International, 29(5-6), 527-540. https://doi.org/10.1016/0963-9969(95) 00045-3

Jonathan, S.G., Fadahunsi, I.F. and Garuba, E.O. (2011).
Fermentation studies during the production of 'iru' from bambara nut (Voandzeia subterranea 1. Thours), an indigenous condiment from SouthWestern Nigeria. Electronic Journal of Environmental, Agricultural and Food Chemistry, 10 (1), 1829-1836.

Kolapo A.L., Popoola T.O.S. and Sanni M.O. (2007). Evaluation of biochemical deterioration of locust bean daddawa and soybean daddawa-two Nigerian condiments. American Journal of Food Technology, 2, 440-445. https://doi.org/10.3923/ajft.2007.440.445

Lues, J.F.R., Ikalafeng, B.K., Maharasoa, M., Shale, K., Malebo, N.J. and Pool, E. (2011). Staphylococci and other selected microbiota associated with indigenous traditional beer. African Journal of Microbiological Research, 5(13), 1691-1696.

Mossel, D.A. (1982). Microbiology of foods. The ecological essentials of assurance and assessment of safety and quality. 3rd ed. Netherlands: University of Utrecht.

Odunfa, S.A. and Adewuyi, E.Y. (1985a). Optimization of process conditions for the fermentation of African locust bean (Parkia biglobosa) (Effect of starter cultures). Chemie Mikrobiologie Technologie Lebensmittel, 9, 6-10.

Odunfa, S.A. and Adewuyi, E.Y. (1985b). Optimization of process conditions for the fermentation of African locust bean (Parkia biglobosa) (Effect of time, temperature and humidity). Chemie Mikrobiologie Technologie Lebensmittel, 9, 118-122.

Odunfa, S.A. and Oyewole, O.B. (1986). Identification of Bacillus species from iru, a fermented African locust bean product. Journal of Basic Microbiology, 26(2), 101-106. https://doi.org/10.1002/ jobm.3620260212

Odunfa, S.A. and Komolafe, O.B. (1989). Nutritional characteristics of Staphylococcus species from fermenting African locus beans. Die Nahrung, 33, 607-615.

Ogbadu, I.J. and Okagbue, R.N. (1988). Fermentation of African locust beans (Parkia biglobosa) seeds: Involvement of different species of Bacillus. Food Microbiology, 5(4), 195-199. https:// doi.org/10.1016/0740-0020(88)90018-4

Ogunjobi, A.A., Adebayo-Tayo, B.C. and Ogunshe, A.A. (2005). Microbiological, proximate analysis and sensory evaluation of processed Irish potato fermented in brine solution. African Journal of Biotechnology, 4, 1409-1412.

Ogunshe, A.A.O, Ayodele, A.E. and Okonko, I.O. (2006). Microbial studies on Aisa: A potential indigenous laboratory fermented food condiment from Albizia saman (Jacq.) F. Mull. Pakistan Journal of Nutrition, 5(1), 51-58 https:// 
doi.org/10.3923/pjn.2006.51.58

Ogunshe, A.A.O, Omotosho, M.O. and Ayansina, D.V.A. (2007). Microbial Studies and Biochemical Characteristics of Controlled fermentation of Afiyo: A Nigerian Fermented Food Condiment from Prosopis Africana (Guill and Perr) Taub. Pakistan Journal of Nutrition, 6(6), 620-627. https:// doi.org/10.3923/pjn.2007.620.627

Ogunshe, A.A.O, Jayeola, A.A. and Ogundimu, T.C. (2008). Microbial studies on laboratory fermented of iregi - a potential food condiment from Delonix regia (Boj. Ex. Hook.). Food, 2(1), 61-64.

Okonko I.O. (2008). Microbiological studies on the production of anyi- a potential condiment made from laboratory fermentation of Samanea saman (Monkey pod) seeds (Jacq.) Merr. Electronic Journal of Environment and Food Chemistry (EJEAFChe) 7 (10):3486-3504.

Omafuvbe, B.O., Shonkan, O.O. and Abiose, S.H. (2000). Microbiological and biochemical changes in the traditional fermentation of soybean for soydaddawa - a Nigerian food condiment. Food Microbiology, 17(5), 469-474. https:// doi.org/10.1006/fmic.1999.0332

Omafuvbe B.O., Abiose, S.H. and Shonukan, O.O. (2002). Fermentation of soybean (Glycine max) for soy-daddawa production by starter cultures of Bacillus. Food Microbiology, 19(6), 561-566. https:// doi.org/10.1006/fmic.2002.0513

Omafuvbe, B.O., Falade, S.O., Osuntogun, B.A. and Adewusi, R.A. (2004). Chemical and biochemical changes in African locus beans (Pakia biglobosa) and melon (Citrullus vulgaris) seeds during Fermentation to Condiments. Pakistan Journal of Nutrition, 3(3), 140-145. https://doi.org/10.3923/ pjn.2004.140.145

Omafuvbe, B.O. (2006). Effect of salt on the fermentation of soybean (Glycine max) into daddawa using Bacillus subtilis as starter culture. African Journal of Biotechnology, 5, 1001-1005.

Pelig-Ba, K.B. (2009). Effect of Ash, KOH and Millet on the Fermentation of Parkia biglobosa seeds to form a condiment. Pakistan Journal of Nutrition, 8(10), 1548-1554. https://doi.org/10.3923/ pjn.2009.1548.1554

Rosen, H. (1957). A modified ninhydrin colorimetric analysis of amino acids. Archives of Biochemistry and Biophysics, 67(1), 10-15. https:// doi.org/10.1016/0003-9861(57)90241-2

Uaboi-Egbenni, P.O., Okolie, P.N., Sobande, A.O., Alao, O., Teniola, O. and Bessong, P.O. (2009). Identification of subdominant lactic acid bacteria in dawadawa (soup condiment) and their evolution during laboratory-scale fermentation of Parkia biglobosa (African locust beans). African Journal of Biotechnology, 8, 7241-7248. 